\title{
Leucobacter chromiiresistens sp. nov., a chromate-resistant strain
}

\author{
Correspondence \\ Johannes Gescher \\ johannes.gescher@biologie. \\ uni-freiburg.de
}

\author{
Gunnar Sturm, ${ }^{1}$ Johanna Jacobs, ${ }^{1}$ Cathrin Spröer, ${ }^{2}$ Peter Schumann ${ }^{2}$ \\ and Johannes Gescher ${ }^{1}$
${ }^{1}$ Institut für Biologie II, Mikrobiologie, Universität Freiburg, 79104 Freiburg, Germany
${ }^{2} \mathrm{DSMZ}$ - Deutsche Sammlung von Mikroorganismen und Zellkulturen GmbH, Inhoffenstraße 7B, 38124 Braunschweig, Germany

\begin{abstract}
A Gram-positive, irregular rod-shaped, non-motile, yellow-pigmented bacterium, strain JG $31^{\top}$, was isolated in the course of identifying chromium-resistant soil bacteria. 16S rRNA gene sequence analysis of the isolated bacterium indicated its phylogenetic position within the genus Leucobacter. Binary 16S rRNA gene sequence alignments of the isolated bacterium with the 11 species of the genus recognized at the time of writing revealed sequence similarities of more than $97 \%$ with Leucobacter alluvii (GenBank accession no: AM072820; 99.4\%), Leucobacter iarius (AM040493; 98.2\%), Leucobacter aridicollis (AJ781047; 97.8\%), Leucobacter komagatae (AB007419; 97.4\%), Leucobacter chironomi (EU346911; 97.1\%) and Leucobacter luti (AM072819; 97.1\%). In contrast, DNA-DNA hybridization experiments showed similarity values below $28 \%$ for DNA samples from the most closely related type strains of $L$. alluvii, $L$. aridicollis and $L$. iarius. Protein analysis by matrix-assisted laser-desorption/ionization time-of-flight mass spectrometry (MALDI-TOF MS) and automated RiboPrinting using the restriction enzyme Pvull differentiated strain JG $31^{\top}$ from all type strains of the genus Leucobacter. The dominant fatty acids of the novel isolate were anteiso- $C_{15: 0}$, anteiso- $C_{17: 0}$ and iso- $C_{16: 0}$, while the quinone system consisted of menaquinones MK-11, MK-10, MK-9 and MK-8. In a B-type cross-linked peptidoglycan, the cell-wall amino acids were alanine, glycine, threonine, glutamic acid and 2,4-diaminobutyric acid. Strain JG $31^{\top}$ was able to grow in a medium containing up to $300 \mathrm{mM}$ $\mathrm{K}_{2} \mathrm{CrO}_{4}$ and showed cellular aggregation in response to chromate stress. From biochemical and genomic analyses, the new strain is considered to represent a novel species of the genus Leucobacter, for which the name Leucobacter chromiiresistens sp. nov. is proposed. The type strain is strain JG $31^{\top}\left(=\mathrm{DSM} 22788^{\top}=\operatorname{CCOS} 200^{\top}\right)$.
\end{abstract}

The genus Leucobacter was described by Takeuchi et al. (1996). At the time of writing, the genus Leucobacter includes 11 species, namely Leucobacter komagatae (Takeuchi et al., 1996), Leucobacter chromiireducens, Leucobacter aridicollis (Morais et al., 2004), Leucobacter albus (Lin et al., 2004), Leucobacter alluvii, Leucobacter luti (Morais et al., 2006), Leucobacter iarius (Somvanshi et al., 2007), Leucobacter tardus (Behrendt et al., 2008), Leucobacter chironomi (Halpern et al., 2009), Leucobacter aerolatus (Martin et al., 2010) and Leucobacter salsicius (Yun et al., 2011). All species of the genus are characterized by 2,4-diaminobutyric acid (DAB) as the diagnostic diamino acid in the B-type cross-linked peptidoglycan.

Abbreviation: DAB, 2,4-diaminobutyric acid.

The GenBank/EMBL/DDBJ accession number for the 16S rRNA gene sequence of strain JG $31^{\top}$ is GU390657.

Three supplementary figures and a supplementary table are available with the online version of this paper.
However, differences can be observed within the general amino acid composition of the peptidoglycan and the occurrence of $\gamma$-aminobutyric acid (GABA), which has only been found in L. albus, L. komagatae and L. chironomi. Species of the genus Leucobacter have been isolated from diverse environmental habitats, such as soil (Lin et al., 2004), air (Martin et al., 2010), activated sludge from chromium-contaminated wastewater (Morais et al., 2006), chironomid egg masses (Halpern et al., 2009) and nematodes (Somvanshi et al., 2007; Muir \& Tan, 2007).

Strain JG $31^{\mathrm{T}}$ was isolated during a series of experiments aimed at identifying chromium-resistant bacteria from uncontaminated soil in July 2007. It was the only bacterium that grew with more than $5 \mathrm{mM}$ chromate $\left(\mathrm{K}_{2} \mathrm{CrO}_{4}\right)$ in the medium. Further investigation demonstrated a very high chromate tolerance of strain JG $31^{\mathrm{T}}$, which is, to the authors' knowledge, the only known bacterium that is capable of growing in medium containing up to $300 \mathrm{mM}$ chromate. 
Taxonomic classification was performed via 16S rRNA gene amplification using universal bacterial primers (27f and 1525r; Rainey et al., 1992). Purified PCR products were sequenced using additional strain-specific primers (490f: GCGTTGTCCGGAATTATTG; 1041f: CGTGTCGTGAGATGTTCG; 1049r: TTTACGAGTGTCCAAAGAG). The assembled sequence was used to determine the phylogenetic position of strain JG $31^{\mathrm{T}}$ by means of binary sequence alignments using the AE2 alignment editor and 16S rRNA gene sequences of all recognized species of the genus Leucobacter. Geneious software (Biomatters) was used to calculate a phylogenetic tree using the neighbour-joining algorithm. Bootstrap values were determined after the analysis of 1000 resamplings (Fig. 1).

The sequence obtained (1460 bp) for strain JG $31^{\mathrm{T}}$ showed more than $97 \%$ similarity to the sequences of $L$. alluvii $(99.4 \%)$, L. iarius $(98.2 \%), L$. aridicollis $(97.8 \%), L$. komagatae $(97.4 \%)$, L. chironomi $(97.1 \%)$ and L. luti (97.1\%), while similarities to the type strains of other recognized species of the genus Leucobacter were between 95.9 and $97 \%$ (Fig. 1). Although the threshold value for $16 \mathrm{~S}$ rRNA gene sequence similarity of two separate species is proposed to be $<98.7 \%$ (Stackebrandt \& Ebers, 2006), DNA-DNA hybridizations were performed using L. iarius $\left(\right.$ DSM $\left.17402^{\mathrm{T}}\right)$, L. aridicollis (DSM $17380^{\mathrm{T}}$ ) and L. alluvii $\left(\right.$ CIP $108819^{\mathrm{T}}$ ) as the three closest relatives to strain JG $31^{\mathrm{T}}$. DNA was isolated from cells disrupted by using a French pressure cell (Thermo Spectronic) and was purified by hydroxyapatite chromatography (Cashion et al., 1977). DNA-DNA hybridization was carried out as described by De Ley et al. (1970) under consideration of the modifications described by Huß et al. (1983) using a Cary 100 Bio UV/VIS-spectrophotometer (Varian) equipped with a Peltier-thermostatted $6 \times 6$ multicell changer and a temperature controller with an in-situ temperature probe. The binary hybridization values and their standard deviations against strain JG $31^{\mathrm{T}}$ were $2.1 \pm 1.48 \%$ for $L$. iarius, $8.4 \pm 2.97 \%$ for $L$. aridicollis and $28.0 \pm 5.16 \%$ for $L$. alluvii. These similarity values were below $70 \%$, which differentiated strain JG $31^{\mathrm{T}}$ from its closest phylogenetic neighbours $L$. alluvii, $L$. iarius and $L$. aridicollis at the species level (Wayne, 1988).

Sample preparation for matrix-assisted laser-desorption/ ionization time-of-flight mass spectrometry (MALDI-TOF MS) protein analysis and recording of mass spectra by using a Microflex L20 instrument (Bruker Daltonics) were carried out as described by Tóth et al. (2008). The dendrogram (see Supplementary Fig. S1 in IJSEM Online) was calculated from mass spectra of strain JG $31^{\mathrm{T}}$ and type strains of the genus Leucobacter by using the BioTyper 2.0 software (Bruker Daltonics). The clusters that appeared in the dendrogram, L. luti/L. chromiireducens subsp. chromiireducens/L. chromiireducens subsp. solipictus and L. komagatae/L. aridicollis/ $L$. albus agreed with the intrageneric phylogenetic structure of the genus Leucobacter as revealed by sequence analysis of the $16 \mathrm{~S}$ rRNA gene (Fig. 1). The results confirmed the close relationship of strain JG $31^{\mathrm{T}}$ to the type strain of $L$. alluvii and differentiated strain JG $31^{\mathrm{T}}$ from the type strains of all species of the genus Leucobacter.

Fully automated ribotyping of PvuII-digested samples was performed with a RiboPrinter system (DuPont Qualicon) as described by Bruce (1996). The dendrogram (Supplementary Fig. S2) calculated by using the BioNumerics software (Applied Maths) demonstrated that strain JG $31^{\mathrm{T}}$ differed in its band pattern from all type strains of the genus Leucobacter.

General strain characteristics such as colony colour, size and shape were determined after $24 \mathrm{~h}$ and $48 \mathrm{~h}$ of growth on LB (lysogeny broth) agar (Bertani, 1951). Strain JG $31^{\mathrm{T}}$ formed pale yellow colonies after $48 \mathrm{~h}$. Microscopic examination showed that strain JG $31^{\mathrm{T}}$ formed irregularshaped rods. The cell size was between $0.33 \mu \mathrm{m}$ and $0.4 \mu \mathrm{m}$ in width and $0.74 \mu \mathrm{m}$ and $1.4 \mu \mathrm{m}$ in length.

In general, phenotypic characterization was conducted using LB medium containing $1 \%(\mathrm{w} / \mathrm{v}) \mathrm{NaCl}$. Cells were

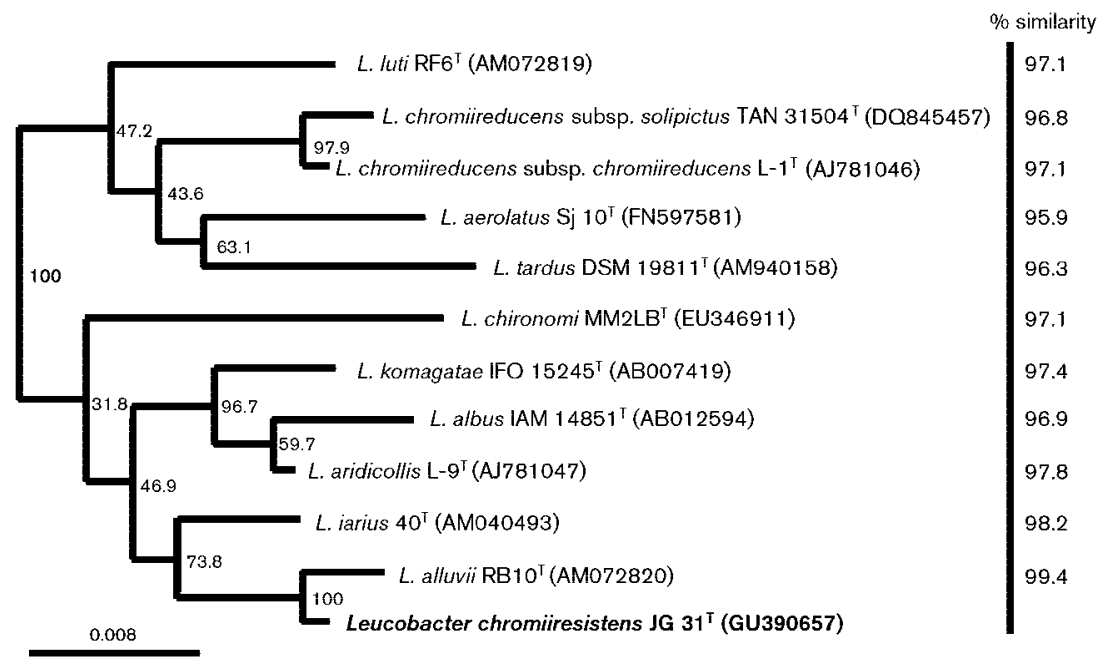

Fig. 1. Phylogenetic tree based on $16 \mathrm{~S}$ rRNA gene sequences. Bootstrap values $>30 \%$ are shown (1000 resamplings). GenBank accession numbers are given in parentheses. The numbers on the right show binary $16 \mathrm{~S}$ rRNA gene sequence similarity values from alignments with strain JG $31^{\top}$. Bar, $0.8 \%$ sequence divergence. 
grown at $25{ }^{\circ} \mathrm{C}, 30{ }^{\circ} \mathrm{C}, 37{ }^{\circ} \mathrm{C}$ and $42{ }^{\circ} \mathrm{C}$ to determine the optimal growth temperature. The $\mathrm{pH}$ range for growth was determined using $\mathrm{LB}$ media with $\mathrm{pH}$ values ranging from $\mathrm{pH} 2$ to 11 at 0.5 intervals. $\mathrm{pH}$ values were adjusted prior to sterilization using $\mathrm{HCl}$ and $\mathrm{NaOH}$. No deviation from the initially adjusted $\mathrm{pH}$ values was detectable during the growth experiments. Determination of substrate utilization was performed in M9 medium (Ausubel et al., 1987) supplemented with $2 \mathrm{mM} \mathrm{MgSO}_{4}$ and $100 \mu \mathrm{M} \mathrm{CaCl}_{2}$. Salt tolerance was tested in LB medium containing 0-11\% $(\mathrm{w} / \mathrm{v}) \mathrm{NaCl}$.

Acid production was analysed using the API $50 \mathrm{CH}$ test panel (bioMérieux) according to the manufacturer's instructions using medium $\mathrm{E}$ (bioMérieux). The incubation temperature was set to $30{ }^{\circ} \mathrm{C}$. Results were scored for up to 5 days according to Morais et al. (2004). Of all the supplied carbohydrates, only aesculin was metabolized by strain JG $31^{\mathrm{T}}$ with a detectable concomitant acid production. Substrate utilization was determined using GP2 Micro Plates (AES Chemunex) according to the manufacturer's instructions except that incubation was carried out at $30{ }^{\circ} \mathrm{C}$ for $24 \mathrm{~h}$. Strain JG $31^{\mathrm{T}}$ showed a unique pattern of substrate utilization when compared with the type strains of $L$. iarius and $L$. alluvii grown under identical conditions (Table 1). Growth under anaerobic conditions was determined using minimal media (Schuetz et al., 2009) containing $0.5 \%$ glycerol as the carbon and electron source and $10 \mathrm{mM}$ potassium nitrate or $20 \mathrm{mM}$ disodium fumarate as the electron acceptor. Anaerobic cultures were grown in Hungate tubes sealed with butyl rubber stoppers. Oxygen was removed from the medium by repeatedly flushing the headspace of each tube for $1.5 \mathrm{~min}$ with nitrogen followed by a $1.5 \mathrm{~min}$ application of vacuum. Nitrogen gas and vacuum cycles were repeated 15 times before the tubes were inoculated. Citrate utilization, anaerobic growth with glucose as the sole carbon and electron source and urease activity were tested using an Oxi/Ferm Tube II (BD).

Oxidase activity was examined by using $1 \% N, N, N^{\prime}$, $N^{\prime}$-tetramethyl-p-phenylenediamine dihydrochloride. Catalase activity was determined via bubble production after addition of $3 \%(\mathrm{v} / \mathrm{v})$ hydrogen peroxide solution.

Peptidoglycan preparations purified according to the method of Schleifer (1985) were obtained after disruption of cells by shaking with glass beads and subsequent trypsin digestion. The amino acids and peptides in cell-wall hydrolysates were analysed by two-dimensional ascending TLC on cellulose plates by using previously described solvent systems (Schleifer, 1985). The amino-terminal amino acid of the interpeptide bridge was detected by dinitrophenylation as described by Schleifer (1985). The molar ratios of amino acids were determined by GC and GC-MS of N-heptafluorobutyryl amino acid isobutyl esters (MacKenzie, 1987; Groth et al., 1996). The hydrolysate $\left(4 \mathrm{M} \mathrm{HCl}, 100{ }^{\circ} \mathrm{C}, 16 \mathrm{~h}\right.$ ) of the preparation of strain JG $31^{\mathrm{T}}$ contained $\mathrm{DAB}$, alanine, glycine, threonine and glutamic acid in a molar ratio of $0.4: 1.8: 1.0: 0.6: 1.0$. The appearance of the peptide Gly-D-Glu in the partial hydrolysate $\left(4 \mathrm{M} \mathrm{HCl}, 100{ }^{\circ} \mathrm{C}, 0.75 \mathrm{~h}\right)$ indicated a B-type cross-linked peptidoglycan. $\gamma$-Aminobutyric acid, present in some other members of the genus Leucobacter (L. albus, L. komagatae and L. chironomi), was not detected. Alanine was found to be the $\mathrm{N}$-terminal amino acid. Polar lipids were extracted (Minnikin et al., 1979) and analysed by two-dimensional TLC (Collins \& Jones, 1980). Phosphatidylglycerol, diphosphatidylglycerol, an unidentified phospholipid and an unidentified glycolipid were detected (Supplementary Fig. S3).

Analysis of menaquinones was performed by HPLC as described previously (Groth et al., 1996). MK-11 was found to be the main menaquinone (59\%). MK-10, MK-9 and MK- 8 were present in lower amounts of $22 \%, 11 \%$ and $5 \%$, respectively.

Cellular fatty acids were extracted, methylated and analysed by GC using the Sherlock Microbial Identification system (MIDI) as described previously (Kämpfer \& Kroppenstedt, 1996). Anteiso- $C_{15: 0}$, anteiso- $C_{17: 0}$ and iso- $C_{16: 0}$ were found to be the major fatty acids of strain JG $31^{\mathrm{T}}$, which was in line with the general fatty acid pattern of the genus (see Supplementary Table S1).

Several species of the genus Leucobacter are known to be resistant to chromium (L. chromiireducens, $L$. aridicollis, $L$. komagatae, L. luti, L. alluvii and L. chironomi) and antibiotics (L. chromiireducens). Therefore, chromate tolerance of strain JG $31^{\mathrm{T}}$ was determined by growth in LB medium supplemented with $\mathrm{K}_{2} \mathrm{CrO}_{4}$ at $30^{\circ} \mathrm{C}$. Surprisingly, strain JG $31^{\mathrm{T}}$ showed growth at concentrations of up to $300 \mathrm{mM}$ $\mathrm{Cr}(\mathrm{VI})$. Antibiotic resistance was observed in LB media containing $\left(\mu \mathrm{g} \mathrm{ml}^{-1}\right)$ : streptomycin (30), gentamicin (15), tetracycline (15), kanamycin (30) and spectinomycin (100). In contrast, addition of $100 \mu \mathrm{g}$ ampicillin $\mathrm{ml}^{-1}$, $20 \mu \mathrm{g}$ chloramphenicol $\mathrm{ml}^{-1}$ and $150 \mu \mathrm{g}$ rifampicin $\mathrm{ml}^{-1}$ resulted in growth inhibition.

In conclusion, based upon the phylogenetic and chemotaxonomic evidence, strain $\mathrm{JG} 31^{\mathrm{T}}$ represents a novel member of the genus Leucobacter, family Microbacteriaceae, for which the name Leucobacter chromiiresistens sp. nov. is proposed.

\section{Description of Leucobacter chromiiresistens sp. nov.}

Leucobacter chromiiresistens (chro.mi.i.re.sis'tens. N.L. neut. n. chromium chromium; L. part. adj. resistens resisting; N.L. part. adj. chromiiresistens chromium resisting).

Cells are Gram-positive-staining, aerobic, non-sporulating, non-motile rods $(0.33-0.4 \times 0.74-1.4 \mu \mathrm{m})$. After $48 \mathrm{~h}$ of growth they form yellow colonies on LB agar. Optimal growth occurs at $30{ }^{\circ} \mathrm{C}$ and at $\mathrm{pH} 7-8$. Cells do not grow at $4{ }^{\circ} \mathrm{C}$ or $42{ }^{\circ} \mathrm{C}$ or below pH 5 or above pH 10 . Growth is observed at $\mathrm{NaCl}$ concentrations from 0 to $8 \%(\mathrm{w} / \mathrm{v})$. 
Table 1. Phenotypic characteristics of strain JG $31^{\top}$ and closely related species of the genus Leucobacter

Strains: 1 , JG $31^{\mathrm{T}} ; 2$, L. alluvii CIP $108819^{\mathrm{T}} ; 3$, L. iarius DSM $17402^{\mathrm{T}}$. All other carbohydrates provided by the test panels were scored as negative and are not listed below. All strains were pre-grown in LB medium at $30{ }^{\circ} \mathrm{C}$. + , Growth or positive test result; -, no growth or negative test result; w, weak growth on Biolog GP2 Micro Plates; NA, no data available.

\begin{tabular}{|c|c|c|c|}
\hline Characteristic & 1 & 2 & 3 \\
\hline Colony pigmentation & Yellow & Cream & White \\
\hline Urease & - & + & - \\
\hline Gelatinase & - & + & - \\
\hline $\mathrm{pH}$ optimum & $7-8$ & $7-8$ & $\mathrm{NA}$ \\
\hline Optimal temperature $\left({ }^{\circ} \mathrm{C}\right)$ & 30 & 30 & 30 \\
\hline \multicolumn{4}{|l|}{ Growth at/in: } \\
\hline $4{ }^{\circ} \mathrm{C}$ & - & + & - \\
\hline $37^{\circ} \mathrm{C}$ & + & + & + \\
\hline $7 \% \mathrm{NaCl}$ & + & + & + \\
\hline $10 \% \mathrm{NaCl}$ & - & - & - \\
\hline \multicolumn{4}{|l|}{ Amino acids in cell wall } \\
\hline $\mathrm{DAB}$ & 0.4 & 0.5 & 0.5 \\
\hline Alanine & 1.8 & 2.4 & 1.5 \\
\hline Glycine & 1.0 & 1.2 & 0.9 \\
\hline Glutamic acid & 1.0 & 1.0 & 1.0 \\
\hline$\gamma$-Aminobutyric acid & - & - & - \\
\hline Threonine & 0.6 & 0.7 & 0.7 \\
\hline \multicolumn{4}{|l|}{ Menaquinones } \\
\hline Major amounts & MK-11 & MK-11 & MK-11 \\
\hline Minor amounts & $\begin{array}{c}\text { MK-10, MK-9, } \\
\text { MK-8 }\end{array}$ & MK-10 & $\begin{array}{l}\text { MK-10, MK- } \\
\text { 9, MK-12 }\end{array}$ \\
\hline \multicolumn{4}{|l|}{$\begin{array}{l}\text { Acid production from } \\
\text { (API } 50 \mathrm{CH}) \text { : }\end{array}$} \\
\hline$N$-Acetylglucosamine & - & - & + \\
\hline Aesculin & + & - & + \\
\hline D-Fructose & - & - & + \\
\hline Glycerol & - & - & + \\
\hline D-Ribose & - & - & + \\
\hline Turanose & - & + & - \\
\hline \multicolumn{4}{|l|}{ Utilization of (Biolog GP2 } \\
\hline Adenosine & + & + & $\mathrm{W}$ \\
\hline L-Alaninamide & + & + & + \\
\hline L-Alanine & + & - & + \\
\hline L-Alanyl glycine & - & + & - \\
\hline L-Asparagine & + & - & - \\
\hline $2^{\prime}$-Deoxyadenosine & + & + & - \\
\hline D-Fructose & - & - & + \\
\hline L-Glutamic acid & - & + & + \\
\hline Glycerol & + & + & + \\
\hline Glycyl L-glutamic acid & - & - & + \\
\hline $\begin{array}{l}p \text {-Hydroxyphenylacetic } \\
\text { acid }\end{array}$ & + & - & + \\
\hline$\alpha$-Ketoglutaric acid & - & + & - \\
\hline Pyruvic acid methyl ester & + & + & + \\
\hline Putrescine & + & + & + \\
\hline Pyruvic acid & + & + & - \\
\hline D-Ribose & - & - & + \\
\hline
\end{tabular}

Table 1. cont.

\begin{tabular}{|llll|}
\hline Characteristic & $\mathbf{1}$ & $\mathbf{2}$ & $\mathbf{3}$ \\
\hline Succinic acid & - & + & - \\
Succinic acid & - & + & - \\
monomethyl ester & & & \\
Thymidine & + & + & - \\
Xylitol & + & + & - \\
Uridine & - & - & $\mathrm{w}$ \\
Tween 40 & + & + & + \\
Tween 80 & + & + & $\mathrm{w}$ \\
\hline
\end{tabular}

Growth rates decrease when the $\mathrm{NaCl}$ concentration exceeds $2 \%(\mathrm{w} / \mathrm{v})$. Catalase activity is detected, whereas oxidase, gelatinase and urease activities are absent. Oxidative acid production is observed for aesculin but not for any other of the API $50 \mathrm{CH}$ carbohydrates after 5 days at $30{ }^{\circ} \mathrm{C}$. Neither nitrate nor fumarate serves as electron acceptor under anaerobic growth conditions. Glucose is not fermented. On Biolog GP2 MicroPlates, utilization of Tween 40, Tween 80 , xylitol, $p$-hydroxyphenylacetic acid, pyruvic acid methyl ester, pyruvic acid, L-alaninamide, L-alanine, L-asparagine, glycerol, adenosine, $2^{\prime}$-deoxyadenosine, thymidine and putrescine is detected. Polar lipids are phosphatidylglycerol and diphosphatidylglycerol. Two unidentified components, one glycolipid and one phospholipid, are also present. The B-type cross-linked peptidoglycan contains alanine, glycine, threonine, glutamic acid and DAB. Major menaquinones are MK-11 and MK-10. The dominant cellular fatty acids are anteiso$\mathrm{C}_{15: 0}$, anteiso- $\mathrm{C}_{17: 0}$ and iso- $\mathrm{C}_{16: 0}$. The cells are highly chromate resistant and able to tolerate up $300 \mathrm{mM} \mathrm{K}_{2} \mathrm{CrO}_{4}$ in the medium, showing aggregation as a phenotypic stress response. The type strain is resistant to $\left(\mu \mathrm{g} \mathrm{ml}^{-1}\right)$ : streptomycin (30), gentamicin (15), tetracycline (15), kanamycin (30) and spectinomycin (100), but sensitive to ampicillin (100), chloramphenicol (20) and rifampicin (150).

The type strain, JG $31^{\mathrm{T}}\left(=\mathrm{DSM} 22788^{\mathrm{T}}=\operatorname{CCOS} 200^{\mathrm{T}}\right)$, was isolated from an uncontaminated soil sample at the University of Freiburg, Germany.

\section{Acknowledgements}

Strain JG $31^{\mathrm{T}}$ was isolated by J.J. and students of the advanced microbiology course of the University of Freiburg in 2007. The authors thank Mrs Anika Wasner and Mrs Bettina Sträubler (both DSMZ) for excellent technical assistance in chemotaxonomic characterization, RiboPrinting and DNA-DNA hybridization analysis.

\section{References}

Ausubel, F. M., Brent, R., Kingston, R. E., Moore, D. D., Seidman, J. G., Smith, J. A. \& Struhl, K. (editors) (1987). Current Protocols in Molecular Biology. New York: Wiley.

Behrendt, U., Ulrich, A. \& Schumann, P. (2008). Leucobacter tardus sp. nov., isolated from the phyllosphere of Solanum tuberosum L. Int $J$ Syst Evol Microbiol 58, 2574-2578. 
Bertani, G. (1951). Studies on lysogenesis. I. The mode of phage liberation by lysogenic Escherichia coli. J Bacteriol 62, 293-300.

Bruce, J. (1996). Automated system rapidly identifies and characterizes microorganisms in food. Food Technol 50, 77-81.

Cashion, P., Holder-Franklin, M. A., McCully, J. \& Franklin, M. (1977). A rapid method for the base ratio determination of bacterial DNA. Anal Biochem 81, 461-466.

Collins, M. D. \& Jones, D. (1980). Lipids in the classification and identification of coryneform bacteria containing peptidoglycans based on 2,4-diaminobutyric acid. J Appl Bacteriol 48, 459-470.

De Ley, J., Cattoir, H. \& Reynaerts, A. (1970). The quantitative measurement of DNA hybridization from renaturation rates. Eur $J$ Biochem 12, 133-142.

Groth, I., Schumann, P., Weiss, N., Martin, K. \& Rainey, F. A. (1996). Agrococcus jenensis gen. nov., sp. nov., a new genus of actinomycetes with diaminobutyric acid in the cell wall. Int J Syst Bacteriol 46, 234239 .

Halpern, M., Shakéd, T., Pukall, R. \& Schumann, P. (2009). Leucobacter chironomi sp. nov., a chromate-resistant bacterium isolated from a chironomid egg mass. Int J Syst Evol Microbiol 59, 665-670.

Huß, V. A. R., Festl, H. \& Schleifer, K. H. (1983). Studies on the spectrophotometric determination of DNA hybridization from renaturation rates. Syst Appl Microbiol 4, 184-192.

Kämpfer, P. \& Kroppenstedt, R. M. (1996). Numerical analysis of fatty acid patterns of coryneform bacteria and related taxa. Can $J$ Microbiol 42, 989-1005.

Lin, Y. C., Uemori, K., de Briel, D. A., Arunpairojana, V. \& Yokota, A. (2004). Zimmermannella helvola gen. nov., sp. nov., Zimmermannella alba sp. nov., Zimmermannella bifida sp. nov., Zimmermannella faecalis sp. nov. and Leucobacter albus sp. nov., novel members of the family Microbacteriaceae. Int J Syst Evol Microbiol 54, 1669-1676.

MacKenzie, S. L. (1987). Gas chromatographic analysis of amino acids as the N-heptafluorobutyryl isobutyl esters. J Assoc Off Anal Chem 70, 151-160.

Martin, E., Lodders, N., Jäckel, U., Schumann, P. \& Kämpfer, P. (2010). Leucobacter aerolatus sp. nov., from the air of a duck barn. Int J Syst Evol Microbiol 60, 2838-2842.

Minnikin, D. E., Collins, M. D. \& Goodfellow, M. (1979). Fatty-acid and polar lipid-composition in the classification of Cellulomonas, Oerskovia and related taxa. J Appl Bacteriol 47, 87-95.

Morais, P. V., Francisco, R., Branco, R., Chung, A. P. \& da Costa, M. S. (2004). Leucobacter chromiireducens sp. nov, and Leucobacter aridicollis sp. nov., two new species isolated from a chromium contaminated environment. Syst Appl Microbiol 27, 646-652.

Morais, P. V., Paulo, C., Francisco, R., Branco, R., Paula Chung, A. \& da Costa, M. S. (2006). Leucobacter luti sp. nov., and Leucobacter alluvii sp. nov., two new species of the genus Leucobacter isolated under chromium stress. Syst Appl Microbiol 29, 414-421.

Muir, R. E. \& Tan, M. W. (2007). Leucobacter chromiireducens subsp. solipictus subsp. nov., a pigmented bacterium isolated from the nematode Caenorhabditis elegans, and emended description of $L$. chromiireducens. Int J Syst Evol Microbiol 57, 2770-2776.

Rainey, F. A., Dorsch, M., Morgan, H. W. \& Stackebrandt, E. (1992). $16 \mathrm{~S}$ rDNA analysis of Spirochaeta thermophila: its phylogenetic position and implications for the systematics of the order Spirochaetales. Syst Appl Microbiol 15, 197-202.

Schleifer, K. H. (1985). Analysis of the chemical composition and primary structure of murein. Methods Microbiol 18, 123-156.

Schuetz, B., Schicklberger, M., Kuermann, J., Spormann, A. M. \& Gescher, J. (2009). Periplasmic electron transfer via the $c$-type cytochromes MtrA and FccA of Shewanella oneidensis MR-1. Appl Environ Microbiol 75, 7789-7796.

Somvanshi, V. S., Lang, E., Schumann, P., Pukall, R., Kroppenstedt, R. M., Ganguly, S. \& Stackebrandt, E. (2007). Leucobacter iarius sp. nov., in the family Microbacteriaceae. Int J Syst Evol Microbiol 57, 682686.

Stackebrandt, E. \& Ebers, J. (2006). Taxonomic parameters revisited: tarnished gold standards. Microbiol Today 33, 152-155.

Takeuchi, M., Weiss, N., Schumann, P. \& Yokota, A. (1996). Leucobacter komagatae gen. nov., sp. nov., a new aerobic grampositive, nonsporulating rod with 2,4-diaminobutyric acid in the cell wall. Int J Syst Bacteriol 46, 967-971.

Tóth, E. M., Schumann, P., Borsodi, A. K., Kéki, Z., Kovács, A. L. \& Márialigeti, K. (2008). Wohlfahrtiimonas chitiniclastica gen. nov., sp. nov., a new gammaproteobacterium isolated from Wohlfahrtia magnifica (Diptera: Sarcophagidae). Int J Syst Evol Microbiol 58, 976-981.

Wayne, L. G. (1988). International Committee on Systematic Bacteriology: announcement of the report of the ad hoc Committee on Reconciliation of Approaches to Bacterial Systematics. Zentralbl Bakteriol Mikrobiol Hyg [A] 268, 433-434.

Yun, J. H., Roh, S. W., Kim, M. S., Jung, M. J., Park, E. J., Shin, K. S., Nam, Y. D. \& Bae, J. W. (2011). Leucobacter salsicius sp. nov. from a salt-fermented food. Int J Syst Evol Microbiol 61, 502-506. 